Bernhard Schink $\cdot$ Volker Thiemann $\cdot$ Heike Laue

Michael W. Friedrich

\title{
Desulfotignum phosphitoxidans sp. nov., a new marine sulfate reducer that oxidizes phosphite to phosphate
}

Received: 20 September 2001 / Revised: 21 January 2002 / Accepted: 21 January 2002 / Published online: 5 March 2002

(C) Springer-Verlag 2002

\begin{abstract}
A new sulfate-reducing bacterium was isolated from marine sediment with phosphite as sole electron donor and $\mathrm{CO}_{2}$ as the only carbon source. Strain FiPS-3 grew slowly, with doubling times of 3-4 days, and oxidized phosphite, hydrogen, formate, acetate, fumarate, pyruvate, glycine, glutamate, and other substrates nearly completely, with concomitant reduction of sulfate to sulfide. Acetate was formed as a side product to a small extent. Glucose, arabinose, and proline were partly oxidized and partly fermented to acetate plus propionate. Growth with phosphite, hydrogen, or formate was autotrophic. Also, in the presence of sulfate, $\mathrm{CO}$ dehydrogenase was present, and added acetate did not increase growth rates or growth yields. In the absence of sulfate, phosphite oxidation was coupled to homoacetogenic acetate formation, with growth yields similar to those in the presence of sulfate. Cells were small rods, $0.6-0.8 \times 2-4 \mu \mathrm{m}$ in size, and gram-negative, with a $\mathrm{G}+\mathrm{C}$ content of $53.9 \mathrm{~mol} \%$. They contained desulforubidin, but no desulfoviridin. Based on sequence analysis of the 16S rRNA gene and the sulfite reductase genes $d s r A B$, strain FiPS-3 was found to be closely related to Desulfotignum balticum. However, physiological properties differed in many points from those of $D$. balticum. These findings justify the establishment of a new species, Desulfotignum phosphitoxidans.
\end{abstract}

Keywords Phosphite oxidation - Sulfate reduction . Energy metabolism - Homoacetogenic fermentation . Desulfotignum sp.

B. Schink (困) · V. Thiemann · H. Laue

Fakultät für Biologie, Universität Konstanz,

Postfach 5560, 78434 Konstanz, Germany

e-mail: Bernhard.Schink@uni-konstanz.de,

Tel.: +49-7531-882140, Fax: +49-7531-882966

M.W. Friedrich

Max Planck-Institut für terrestrische Mikrobiologie,

Karl von Frisch-Strasse, 35043 Marburg, Germany

\section{Introduction}

The element phosphorus occurs in biochemistry nearly exclusively in the redox state +5 , as phosphate. However, phosphonic (+3) and phosphinic (+1) acids are found as secondary metabolites (Ternan et al. 1998) or as constituents of phosphonolipids in several organisms (Horiguchi et al. 1984). Phosphonates are used by various bacteria as phosphorus source in assimilatory synthesis of cell mass (Ternan et al. 1998).

Chemical reduction of phosphate to phosphine $\left(\mathrm{PH}_{3}\right)$ via phosphite, hypophosphite and phosphorus has to proceed through steps of extremely low redox potential, i.e. $-690,-913,-922$ and $--525 \mathrm{mV}$ at $\mathrm{pH} 7.0$ (calculated after Weast et al. 1988). Therefore, reduction of phosphate for biosynthesis of organophosphonic acids requires significant energy input in the form of ATP (Kim et al. 1998). However, in the past, reduction of phosphate to phosphine was repeatedly assumed to occur also as a respiratory process coupled to biomass oxidation (Barrenscheen and Beckh-Widmannstetter 1923; Rudakow 1929; Devai et al. 1988; Gassmann and Glindemann 1993), but these reports could never be substantiated in defined cultures, as had to be expected on the basis of the redox potentials mentioned above. Traces of phosphine have been detected in certain anoxic environments such as sediments (Gassmann and Schorn 1993; Devai and DeLaune 1995), paddy fields (Tsubota 1959; Han et al. 2000), and manure samples (Devai et al. 1999), but it has never been proven that its formation was caused by biological phosphate reduction. Some of these phosphine findings are today interpreted as the result of a biologically enhanced hydrolysis of phosphide-rich metallic iron or steel (Glindemann et al. 1998). Traces of phosphine are also formed in undefined anaerobic cultures obtained from sewage sludge or animal feces (Rutishauser and Bachofen 1999; Jenkins et al. 2000), but again the origin of this phosphine remains obscure.

Nonetheless, if phosphine can hardly be formed by reduction of phosphate, it appeared promising to examine phosphite as an electron source for microbial energy me- 
tabolism because electrons are released at an unusually low redox potential $\left(E_{0}{ }^{\prime}=-690 \mathrm{mV}\right)$. To date, phosphite and hypophosphite could only be shown to serve as phosphorus source in the assimilatory metabolism of aerobic (Casida 1960; Malacinski and Konetzka 1966; Metcalf and Wolfe 1998; Garcia Costas et al. 2001) and anaerobic (Foster et al. 1978) bacteria, but quantitative phosphite oxidation as a type of energy metabolism has never been documented.

Here we describe a new sulfate-reducing bacterium that oxidizes phosphite to phosphate to provide electrons for energy metabolism with either sulfate or $\mathrm{CO}_{2}$ as electron acceptor. Sequence analysis of the $16 \mathrm{~S}$ rRNA gene and the siroheme sulfite reductase genes $d s r A B$ confirmed a relatedness of this strain to other sulfate-reducing bacteria. A short report on this new biologically catalyzed redox reaction of phosphorus has been published (Schink and Friedrich 2000).

\section{Materials and methods}

\section{Medium and growth conditions}

Bacteria were enriched and cultivated in a bicarbonate-buffered, sulfide-reduced anoxic mineral medium with $10 \mathrm{mM}$ sulfate. The salinity of the medium was adapted to freshwater or seawater conditions (Widdel and Pfennig 1981) and contained trace elements including selenate and tungstate and a seven-vitamins solution. The medium was dispensed in 50-ml screw-cap bottles, in 1-1 infusion bottles, or in 5-1 flasks sealed with rubber septa with a $\mathrm{N}_{2} / \mathrm{CO}_{2}(90: 10, \mathrm{v} / \mathrm{v})$ headspace, or in 22-ml screw-capped tubes. Parallel enrichments were started also with sulfate-free medium. Desulfotignum balticum strain $\operatorname{Sax}^{\mathrm{T}}$ (DSM 7044) and Desulfospira joergensenii strain B331 (DSM 10085) were grown in seawater medium as described above. For determination of the $\mathrm{pH}$ optimum, the medium was buffered with additional $50 \mathrm{mM}$ 4-(2-hydroxyethyl)-1-piperazine ethanesulfonate (HEPES). Substrates were added from concentrated stock solutions, to final concentrations of 2-10 mM. Solutions of oxygen-sensitive compounds were prepared anoxically and sterilized by filtration. Cultures were usually incubated at $28-30^{\circ} \mathrm{C}$, and growth was recorded measuring the optical density at $578 \mathrm{~nm}$ in cuvettes with a $1-\mathrm{cm}$ light path.

Pure cultures were obtained by repeated serial dilution in agar media as described by Widdel and Bak (1992). Purity was checked microscopically in cultures grown in mineral media with $10 \mathrm{mM}$ phosphite and in media containing $0.05 \%(\mathrm{w} / \mathrm{v})$ yeast extract plus $5 \mathrm{mM}$ glucose and $5 \mathrm{mM}$ fumarate.

\section{Analytical procedures}

Phosphite and phosphate were separated by HPLC on an Aminex HPX-87-H column, $300 \times 7.8 \mathrm{~mm}$ (Biorad, Munich), at $40^{\circ} \mathrm{C}$ with

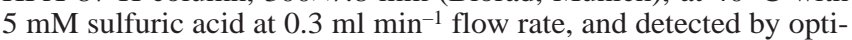
cal diffraction (detector ERC-7512, Erma Sykam, Gilching, Germany). Under these conditions, phosphite eluted after $16 \mathrm{~min}$, and phosphate after $18 \mathrm{~min}$.

Sulfide was determined as described by Cline (1969). Fatty acids and alcohols were analyzed by gas chromatography (Platen and Schink 1987) or by HPLC (Brune and Schink 1990). Protein was quantified with a commercial assay kit based on Coomassie brilliant blue staining (Pierce), with bovine serum albumin as standard.

The G+C content of the DNA was measured by HPLC (Tamaoka and Komagata 1984) after enzymatic digestion of the isolated DNA (Cashion et al. 1977; Mesbah et al. 1989).

For quantification of cell dry mass, a 1-1 culture was gassed with $\mathrm{CO}_{2}$ to strip off hydrogen sulfide, centrifuged at $20,000 \times g$ for
$40 \mathrm{~min}$, washed with $200 \mathrm{ml} 20 \mathrm{mM}$ ammonium acetate, $\mathrm{pH}$ 5.0, again centrifuged, and dried to constant weight at $60^{\circ} \mathrm{C}$.

\section{Sequence analysis of $16 \mathrm{~S}$ rRNA and $d s r A B$ genes}

Nearly full-length16S rRNA gene fragments were amplified from genomic DNA of pure cultures using primers 27F/1492R (Lane 1991) as described previously (Friedrich 2002). 16S rDNA PCR products were sequenced using primers 27F, 533R, 907R (Weisburg et al. 1991) 1114F, and 1368R (Ferris and Ward 1997).

A $\sim 1.9-\mathrm{kb}$ fragment encompassing parts of the dissimilatory sulfite reductase genes $d s r A$ and $d s r B$ was amplified from pure culture DNA using primers DSR1-F and DSR4-R (Wagner et al. 1998). ds $r A B$ PCR products amplified from FiPS-3 and reference strains were directly sequenced using primers DSR1F, DSR4R, and the sequencing primers DSR6F, DSR7F, DSR8F, DSR9F, and DSR10F (Friedrich 2002). The $d s r A B$ PCR fragment obtained from Desulfotignum balticum strain $\operatorname{Sax}^{\mathrm{T}}$ (DSM 7044) was cloned into Escherichia coli JM 109 using a TA-vector system, and randomly selected clones $(n=4)$ were sequenced using vector-targeting primers M13f $/ \mathrm{M} 13 \mathrm{r}$ and DSR-sequencing primers as described previously (Rotthauwe et al. 1997).

Sequence data were analyzed using the ARB [version 2.5b; Ludwig et al. (1999) ARB: a software environment for sequence data. Technische Universität München, Munich, Germany. http://www.biol.chemie.tu-muenchen.de/pub/ARB/] and Phylip software package [J. Felsenstein (2001), PHYLIP (Phylogeny Inference Package) version 3.6; Department of Genetics, University of Washington, Seattle] as described previously in detail (Friedrich 2002). 16S rRNA gene sequences were phylogenetically analyzed using distance-matrix (NEIGHBOR, Jukes and Cantor model; Kimura 2 parameter model) and parsimony (DNAPARS), including only nucleotide positions with $>50-100 \%$ invariance of all $\delta$-Proteobacteria.

DsrAB amino acid sequences deduced from nucleotide sequences were analyzed similarly using distance matrix-based (NEIGHBOR, Dayhoff PAM001 model) and parsimony (PROTPARS) methods as described in detail (Friedrich 2002). Regions of ambiguous identity and indels not present in all sequences analyzed were excluded, yielding an amino acid data set with 563 positions for the concatenated data set of the $\alpha$ - and $\beta$-subunit amino acid sequences. Statistical support for all tree topologies was obtained by bootstrap resampling $(n=1,000)$.

Sequences were deposited in the GenBank database under the accession numbers AF420288 and AF420289 (16S rRNA genes) and AF420282 to AF420287 (dsrAB genes).

\section{Enzyme assays in cell-free extracts}

Cells of a 1-1 culture in the late-exponential growth phase were harvested in an anoxic chamber (Coy, Ann Arbor, Mich., USA) containing an $\mathrm{N}_{2} / \mathrm{H}_{2}$ atmosphere $(95: 5, \mathrm{v} / \mathrm{v})$, centrifuged at $13,000 \times g$ for $20 \mathrm{~min}$, and washed with anoxic $100 \mathrm{mM}$ potassium phosphate buffer, $\mathrm{pH}$ 7.0. Cell-free extracts were prepared anoxically by passing resuspended cells two to three times through a chilled French press cell at $138 \mathrm{MPa}$. Cell debris was removed by centrifugation at $20,000 \times g$ for $20 \mathrm{~min}$.

Cell-free extracts were examined for the presence of cytochromes by spectrophotometry in a double-beam spectrophotometer (Uvikon 930, Kontron, Zürich, Switzerland). Cytochromes $b$ and $c$ were differentiated according to Weston and Knowles (1973).

Desulfoviridin was checked for after the method of Postgate (1959) based on its red fluorescence in short-wavelength light (365 nm) after alkalinization. Desulforubidin was enriched chromatographically and identified by absorption spectroscopy (after Friedrich and Schink 1995). A cytoplasmic cell fraction was loaded on a 5-ml High Trap Q anion-exchange column (Pharmacia, Freiburg, Germany) equilibrated with $20 \mathrm{mM}$ Tris/ $\mathrm{HCl}, \mathrm{pH} 8.0$ (buffer A). Desulforubidin was eluted with a $\mathrm{NaCl}$ step-gradient $(200,250,300$, and $400 \mathrm{mM}$, and $1 \mathrm{M} \mathrm{NaCl})$ at $400 \mathrm{mM} \mathrm{NaCl}$. Fractions were analyzed spectroscopically, and the brown-red frac- 
tions with the highest $398 \mathrm{~nm} / 545 \mathrm{~nm}$-ratio were pooled. To concentrate these fractions, the protein was loaded on a 1-ml High Trap Q column, and eluted with $1 \mathrm{M} \mathrm{NaCl}$. The concentrated sample was then applied to a Superose 12 gel-filtration column $(10 \times 300 \mathrm{~mm}$, Pharmacia) equilibrated with buffer A containing $150 \mathrm{mM} \mathrm{NaCl}$. The fractions with the highest $398 \mathrm{~nm} / 545 \mathrm{~nm}$ ratio were concentrated using a 1-ml High Trap Q column, and then applied to a Superdex 200 preparatory grade gel-filtration column (16×600 mm, Pharmacia) equilibrated with buffer A containing $150 \mathrm{mM} \mathrm{NaCl}$. Finally, the desulforubidin-containing fractions were loaded on a Mono Q anion-exchange column $(10 \times 50 \mathrm{~mm}$, Pharmacia) equilibrated with buffer $\mathrm{A}$. The red desulforubidincontaining fractions were collected and the absorption spectrum was recorded.

Enzyme activities were measured anoxically at $25^{\circ} \mathrm{C}$, either discontinuously by HPLC or continuously by photometry. Acetate kinase (E.C. 2.7.2.1) and phosphotransacetylase (EC 2.3.1.8) were assayed according to Bergmeyer et al. (1974a, b). Carbon monoxide dehydrogenase (E.C. 1.2.99.2) was measured with benzyl viologen according to Diekert and Thauer (1978), and 2-oxoglutarate synthase analogous to carbon monoxide dehydrogenase with 2-oxoglutarate as electron donor in the presence of coenzyme A. ATP sulfurylase (E.C. 2.7.7.4) was assayed in a coupled test system via ATP formation from adenosine phosphosulfate plus pyrophosphate (Dahl and Trüper 1994). APS reductase (E.C. 1.8.99.2) was measured following oxidative formation of APS from sulfite plus AMP with potassium hexacyanoferrate as electron acceptor (Lampreia et al. 1994)

Assays for a phosphite-oxidizing enzyme activity were carried out analogous to carbon monoxide dehydrogenase, with either methyl viologen, benzyl viologen, $\mathrm{NAD}^{+}$, dichlorophenol indophenol, methylene blue, or potassium hexacyanoferrate as electron acceptor, and phosphate, Tris or HEPES as buffers, at pH 5.0 - 9.0, in the presence or absence of AMP, ADP, ATP, acetate, succinate, $\mathrm{MgCl}_{2}$, dithionite, titanium(III)NTA, or phosphate.

SDS-PAGE was carried out after the method of Laemmli (1970) on a $12 \%$ polyacrylamide gel.

\section{Chemicals}

All chemicals were of analytical or reagent grade quality and were obtained from Boehringer (Mannheim, Germany), Eastman Kodak (Rochester, N.Y., USA), Fluka (Neu-Ulm, Germany), Merck (Darmstadt, Germany), Pharmacia (Freiburg, Germany), Serva (Heidelberg, Germany), and Sigma (Deisenhofen, Germany). Gases were purchased from Messer-Griesheim (Darmstadt, Germany), and Sauerstoffwerke Friedrichshafen (Friedrichshafen, Germany).

\section{Results}

Enrichment and isolation

of anaerobic phosphite oxidizers

Phosphite-oxidizing anaerobic bacteria were enriched in sulfide-reduced mineral media, with sulfate as electron acceptor and samples from marine or freshwater sediments as inoculum. Growing cultures developed within 3 months in six out of eleven enrichment cultures, as analyzed by sulfide formation, both with marine and with freshwater inocula. The sulfide-forming activity could be transferred repeatedly into subcultures and was associated with bacterial growth and turbidity formation. Subcultures took 3-6 weeks for growth after transfer of $10 \%$ of inoculum. Control experiments with uninoculated cultures or with cultures containing autoclaved cells gave no indication of phosphite oxidation. Parallel enrichments in the absence of sulfate grew as well, although these cultures usually took longer (5-10 weeks) to reach maximal cell density. After three to four transfers, rather similar, rodshaped bacteria dominated the microscopic picture in all cultures. Two pure cultures of phosphite-oxidizing sulfate-reducing bacteria, strains FiPS-3 and FiPS-5, were finally obtained by three subsequent serial dilutions in deep-agar tubes from an enrichment culture originating from marine sediments taken at the fish market right off the Canal Grande in Venice, Italy. Both were very similar with respect to cell morphology and 16S rRNA sequence data; strain FiPS-3 was characterized in detail.

\section{Morphology}

Colonies of strain FiPS-3 in agar medium were yellowbrown, disc-shaped and small, about $0.5-1 \mathrm{~mm}$ in diameter. Cells were straight rods, $0.6-0.8 \times 2-4 \mu \mathrm{m}$ in size, nonmotile, with round to slightly pointed ends (Fig. 1A). Cells always kept a certain minimum distance from each other, indicating that they were surrounded by a non-refractile capsule. In enrichment cultures, aggregates were often observed which appeared to stick together with their cell ends (Fig. 1B).

\section{Growth physiology and stochiometry} of substrate oxidation

Under optimal conditions ( $\mathrm{pH} 7.2, \mathrm{~T}=30^{\circ} \mathrm{C}$ ), strain FiPS-3 grew with $10 \mathrm{mM}$ phosphite plus $10 \mathrm{mM}$ sulfate, with a doubling time of 3 days. Growth was accompanied by stoichiometric phosphite oxidation to phosphate with simultaneous sulfate reduction, roughly at a 4:1 stoichiometry. When cultures were stored in the cold room $\left(4^{\circ} \mathrm{C}\right)$ after growth, the formed phosphate precipitated in the medium, forming typical crystals of struvite $\left(\mathrm{MgNH}_{4} \mathrm{PO}_{4}\right.$; Fig. 1C) as confirmed by X-ray diffraction analysis. The same occurred also at room temperature when higher substrate concentrations (>20 mM phosphite) were applied.

Strain FiPS-3 oxidized fumarate and malate to $\mathrm{CO}_{2}$, and it also (slowly) oxidized hydrogen and formate. Glucose, arabinose and proline were partly oxidized to $\mathrm{CO}_{2}$ and partly fermented to acetate plus propionate (Table 1). Growth with all these alternative substrates was slow, with doubling times of at least 3 days. Lithotrophic growth with phosphite or with hydrogen was not enhanced in rate or yield by the additional presence of acetate, indicating that this strain covers all its carbon assimilation through autotrophic $\mathrm{CO}_{2}$ fixation. There was no detectable growth with acetate as sole electron source; however, if acetate was supplied together with hydrogen, it was partly oxidized as well. No growth was found with hypophosphite $(5 \mathrm{mM})$, propionate, butyrate, lactate, ethanol, propanol, or fructose. Several further substrates utilized are listed in Table 2 and in the species description at the end of the Discussion section. Instead of sulfate, also thiosulfate or sulfite was reduced to sulfide. Sulfite was tolerated up to 

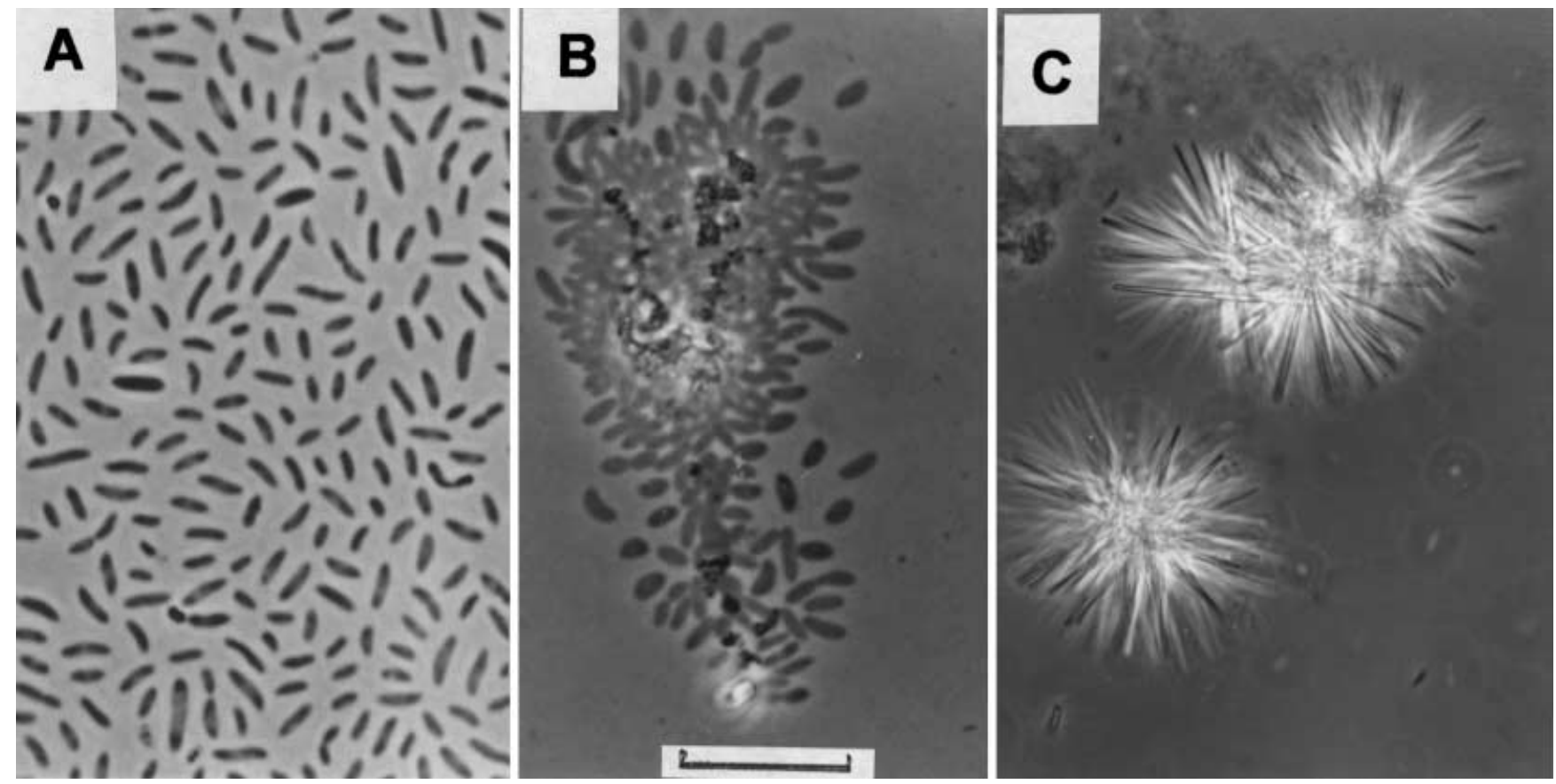

Fig. 1A-C Phase-contrast photomicrographs of phosphite-oxidizing anaerobes grown with $10 \mathrm{mM}$ sodium phosphite plus $10 \mathrm{mM}$ sodium sulfate in bicarbonate-buffered mineral medium. Scale bar $10 \mu \mathrm{m}$ for all three panels. A Pure culture of strain FiPS-3. B Cells similar to strain FiPS-3 dominating in enrichment cultures. C Crystals of struvite precipitated in phosphite-grown cultures after cooling

$5 \mathrm{mM}$ if fumarate was the electron donor; with phosphite as electron source, sulfite inhibited growth at $1.5-2.0 \mathrm{mM}$ concentration.

Growth with phosphite was possible also in the absence of sulfate, with $\mathrm{CO}_{2}$ as sole electron acceptor. Under these conditions, acetate was formed as main reduced product, sometimes together with small amounts of propionate and butyrate (Table 1). Turbidity and acetate formation were proportional to the amount of phosphite supplied, in the range of 5-20 mM phosphite. No fermentative growth was observed with formate, proline, or pyruvate as substrates.

Strain FiPS-3 grew with $10 \mathrm{mM}$ phosphite in media containing $0.5 \%-3 \%(\mathrm{w} / \mathrm{v}) \mathrm{NaCl}$, with an optimum at $2 \%$ $\mathrm{NaCl}$. The $\mathrm{pH}$ dependence of growth was checked with fumarate as substrate in order to avoid $\mathrm{pH}$-dependent precipitations of phosphate salts. The doubling time was lowest in the range of $\mathrm{pH} 6.9-7.2$ and about three times higher at $\mathrm{pH} 5$ or $\mathrm{pH}$ 8. Growth was observed between 15
Table 1 Electron balances for growth of strain FiPS-3 with various substrates in the presence of $10 \mathrm{mM}$ sulfate. Growth yields were calculated from net $\mathrm{OD}_{578}$ values via an experimentally determined conversion factor $\left(\mathrm{OD}_{578}=1\right.$ corresponds to $258 \pm 12 \mathrm{mg}$ dry cell mass per liter). Electrons in cell mass were calculated using the empirical formula $\left\langle\mathrm{C}_{4} \mathrm{H}_{7} \mathrm{O}_{3}\right\rangle$ (equivalent $\left\langle\mathrm{C}_{4} \mathrm{H}_{8} \mathrm{O}_{2} \mathrm{~N}\right\rangle$ ). Thus, $1 \mathrm{mg}$ cell mass is equivalent to $0.165 \mathrm{meq}$ electrons

\begin{tabular}{|c|c|c|c|c|c|c|c|c|}
\hline $\begin{array}{l}\text { Substrate } \\
\text { provided }(\mathrm{mM})\end{array}$ & Net $\mathrm{OD}_{578}$ & \multicolumn{3}{|c|}{ Products (mM) } & $\begin{array}{l}\text { Growth yield }{ }^{b} \\
(\mathrm{~g} / \mathrm{mol})\end{array}$ & $\begin{array}{l}\text { Electrons in } \\
\text { products } \\
(\mathrm{meq} / \mathrm{l})\end{array}$ & $\begin{array}{l}\text { Electrons in } \\
\text { cell mass } \\
(\mathrm{meq} / \mathrm{l})\end{array}$ & $\begin{array}{l}\text { Electron } \\
\text { recovery } \\
(\%)\end{array}$ \\
\hline Formate (10) & 0.12 & 1.25 & 0.34 & - & 4.85 & 12.8 & 5.1 & 89 \\
\hline Fumarate (5) & 0.27 & 5.9 & 0.22 & - & 17.0 & 49 & 11.6 & 101 \\
\hline Glucose (5) & 0.19 & 1.2 & 3.4 & 3.8 & $(14.7)^{\mathrm{c}}$ & 80.5 & 8.1 & 75 \\
\hline Betaine (5) & 0.40 & 9.2 & 4.23 & - & 23.2 & 107 & 17.1 & 103 \\
\hline Proline (10) & 0.61 & 17.5 & 1.55 & 1.80 & 20.0 & 177.2 & 26.0 & 93.5 \\
\hline Glutamate (5) & 0.27 & 5.5 & 0.21 & - & $(27.5)^{\mathrm{c}}$ & 45.6 & 11.6 & 64 \\
\hline Phosphite $(10)^{\mathrm{a}}$ & 0.24 & - & 1.22 & - & 12.8 & 9.7 & 10.2 & 99.5 \\
\hline
\end{tabular}

${ }^{\mathrm{a}}$ Growth in the absence of sulfate after four transfers in sulfate-free medium. Sometimes also traces of propionate and butyrate $(<0.2 \mathrm{mM})$ were formed
bYield referring to the amount of dissimilated substrate

cValues only preliminary; referring to the amount of substrate converted to detected reaction products 
Table 2 Comparison of physiological and cytological properties of strain FiPS-3 with those of related bacteria. Data for D. balticum taken from Kuever et al. (2001), for D. joergensenii from Finster et al. (1997), unless specified otherwise

\begin{tabular}{|c|c|c|c|}
\hline Property & $\begin{array}{l}\text { Strain } \\
\text { FiPS-3 }\end{array}$ & $\begin{array}{l}\text { D. balticum } \\
\text { strain } \operatorname{Sax}^{\mathrm{T}}\end{array}$ & $\begin{array}{l}\text { D. joergensenii } \\
\text { strain } \mathrm{B} 331^{\mathrm{T}}\end{array}$ \\
\hline \multicolumn{4}{|l|}{ Oxidation of } \\
\hline Phosphite & + & $-^{\mathrm{d}}$ & $-^{\mathrm{d}}$ \\
\hline Formate & + & + & + \\
\hline $\mathrm{H}_{2} / \mathrm{CO}_{2}$ & + & + & + \\
\hline Acetate & $-{ }^{\mathrm{a}}$ & + & - \\
\hline Fumarate & + & + & + \\
\hline Maleate & $w^{b}$ & + & + \\
\hline Malate & + & + & + \\
\hline Succinate & $w^{b}$ & + & + \\
\hline Lactate & - & + & + \\
\hline Pyruvate & + & + & + \\
\hline Butyrate & - & + & + \\
\hline Crotonate & - & + & + \\
\hline Glutarate & - & + & + \\
\hline 2-Oxoglutarate & - & + & + \\
\hline 3-Oxoglutarate & - & + & + \\
\hline Glutamate & + & $+^{\mathrm{d}}$ & $(+)^{\mathrm{e}}$ \\
\hline Glucose & + & $-\mathrm{d}$ & - \\
\hline Arabinose & + & $-^{\mathrm{d}}$ & $--^{\mathrm{d}}$ \\
\hline Xylose & + & $-{ }^{\mathrm{d}}$ & $-^{\mathrm{d}}$ \\
\hline Glycine & + & $+^{\mathrm{d}}$ & $(+)^{e}$ \\
\hline Betaine & + & $+^{\mathrm{d}}$ & + \\
\hline Proline & + & $+^{\mathrm{d}}$ & + \\
\hline Choline & - & n.d. & + \\
\hline Yeast extract & + & + & + \\
\hline \multicolumn{4}{|l|}{ Reduction of } \\
\hline Sulfite & $t^{3}$ & + & + \\
\hline Thiosulfate & + & + & + \\
\hline Sulfur & - & $-\mathrm{d}$ & + \\
\hline Nitrate & - & - & - \\
\hline $\begin{array}{l}\mathrm{G}+\mathrm{C} \text { content } \\
(\mathrm{mol} \%)\end{array}$ & 53.9 & $52.7^{\mathrm{d}}$ & 49.9 \\
\hline Desulfoviridin & - & - & - \\
\hline
\end{tabular}

and $30^{\circ} \mathrm{C}$, with the highest rate at $30^{\circ} \mathrm{C}$; no growth was observed at $37^{\circ} \mathrm{C}$.

The stoichiometry of phosphite oxidation and concomitant sulfide formation is documented in Table 1. The molar growth yield was $9.3 \mathrm{~g}$ dry mass per mol of phosphite oxidized, about half as much with formate and twice as much with fumarate as substrate. Also, in the absence of sulfate, phosphite oxidation was coupled to substantial cell mass formation $(8.3 \mathrm{~g}$ per mol). The high molar growth yield with betaine as compared to glycine indicates that the methyl groups were oxidized as well. Furthermore, proline and glutamate were good substrates causing high cell yields, whereas glucose and arabinose allowed only rather low growth yields.
Pigments and $\mathrm{G}+\mathrm{C}$ content of the DNA

Dithionite-reduced minus air-oxidized redox difference spectra of cell-free extracts exhibited absorption maxima at 551,523 , and $419 \mathrm{~nm}$, as typical of $c$-type cytochromes. The major part of these cytochromes was found in the cytoplasmic and periplasmic fraction, and was identified as a $c$-type cytochrome after extraction and precipitation with acetone/HCl. Pyridine hemochromes were extracted from crude cell-free extracts and showed absorption spectra with maxima at 603, 550, 535, 527 and $414 \mathrm{~nm}$, indicating that the membranes contained a substantial amount of cytochromes with non-covalently bound chromophores, e.g., $b$-type cytochromes.

Excitation with short-wave light of cell-free extracts in alkaline solution did not provide any indications of the presence of desulfoviridin. A desulforubidin preparation from cell-free extracts prepared by enrichment as described in Materials and methods exhibited an absorption spectrum with maxima at 545, 398 and $280 \mathrm{~nm}$. The absorption ratio at $398 \mathrm{~nm} / 454 \mathrm{~nm}(4.0)$ and at $398 \mathrm{~nm} / 280 \mathrm{~nm}$ (0.65) indicated that this preparation was nearly pure desulforubidin (Friedrich and Schink 1995).

The $\mathrm{G}+\mathrm{C}$ content of the DNA of strain FiPS-3 was $53.9 \pm 0.5 \mathrm{~mol} \%$.

\section{Enzyme activities}

Some key enzymes of energy and carbon metabolism were checked for to obtain a more detailed understanding of the metabolic properties of this new bacterium. In cell-free extracts of phosphite-plus-sulfate-grown cells, neither phosphotransacetylase nor acetate kinase could be detected at substantial activity. Measurement of acetate kinase was impeded by high background ATPase activity, which did not allow the detection of a significant rate increase upon acetate addition. Carbon monoxide dehydrogenase (acetyl-CoA synthase) was found at high activity $\left[1.21 \pm 0.08 \mu \mathrm{mol} \mathrm{min}{ }^{-1}\right.$ $\left.(\mathrm{mg} \text { protein })^{-1}\right]$, as well as ATP sulfurylase $[0.93 \pm 0.15$ $\mu \mathrm{mol} \mathrm{min}^{-1}$ (mg protein $)^{-1}$ ] and adenosine phosphosulfate (APS) reductase [0.61-0.79 $\mu \mathrm{mol} \mathrm{min}^{-1}$ (mg protein $)^{-1}$. ATP sulfurylase activity was independent of measurement under air or under nitrogen gas; APS reductase activity was about $30 \%$ higher under anoxic conditions than under air. No activity was found for 2-oxoglutarate synthase. The physiological substrate turnover of cells growing with phosphite as calculated from the maximal growth rate and the molar growth yield was in the range of 0.03-0.05 $\mu \mathrm{mol}$ phosphite $\mathrm{min}^{-1}$ (mg protein) ${ }^{-1}$.

Numerous efforts were started to measure a phosphiteoxidizing enzyme activity in cell-free extracts. Although a variety of different electron acceptors of a broad range of redox potentials was tested, we could never detect specific acceptor reduction upon addition of phosphite. These experiments were carried out with various buffers at $\mathrm{pH}$ 5.0-9.0, in the absence or presence of numerous additions, e.g., AMP, ADP, ATP, acetate, succinate, $\mathrm{MgCl}_{2}$, dithionite, titanium(III)NTA, or phosphate, or combina- 


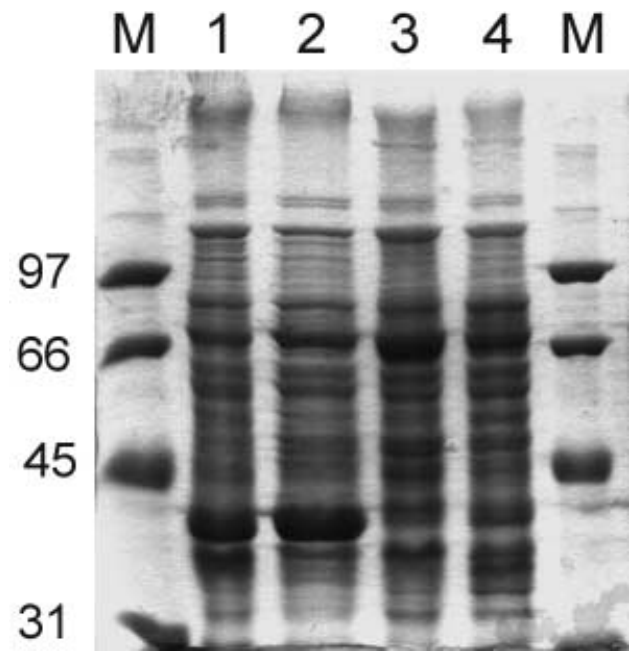

Fig. 2 SDS-PAGE of cell-free extracts of strain FiPS-3 after growth with various substrates. Lanes: $M$ Marker proteins, 1 cells grown with phosphite plus sulfate, 2 cells grown with phosphite plus $\mathrm{CO}_{2}, 3$ cells grown with fumarate plus sulfate, 4 cells grown with fumarate plus thiosulfate

tions thereof, but no phosphite-specific acceptor reduction was observed. If APS reductase was measured in the presence of phosphite, the latter had no influence on the measurable APS reductase activity. The same was found with a purified APS reductase preparation of Desulfovibrio desulfuricans strain Essex.

SDS-PAGE of cell-free extracts prepared from cells grown with phosphite exhibited at least one specific protein band of a molecular mass of about $42 \mathrm{kDa}$ which was not observed in extracts of cells grown either with fumarate plus sulfate or with fumarate plus thiosulfate (Fig.2). This protein fraction may be specifically involved in phosphite oxidation.

\section{A. 16S rDNA}

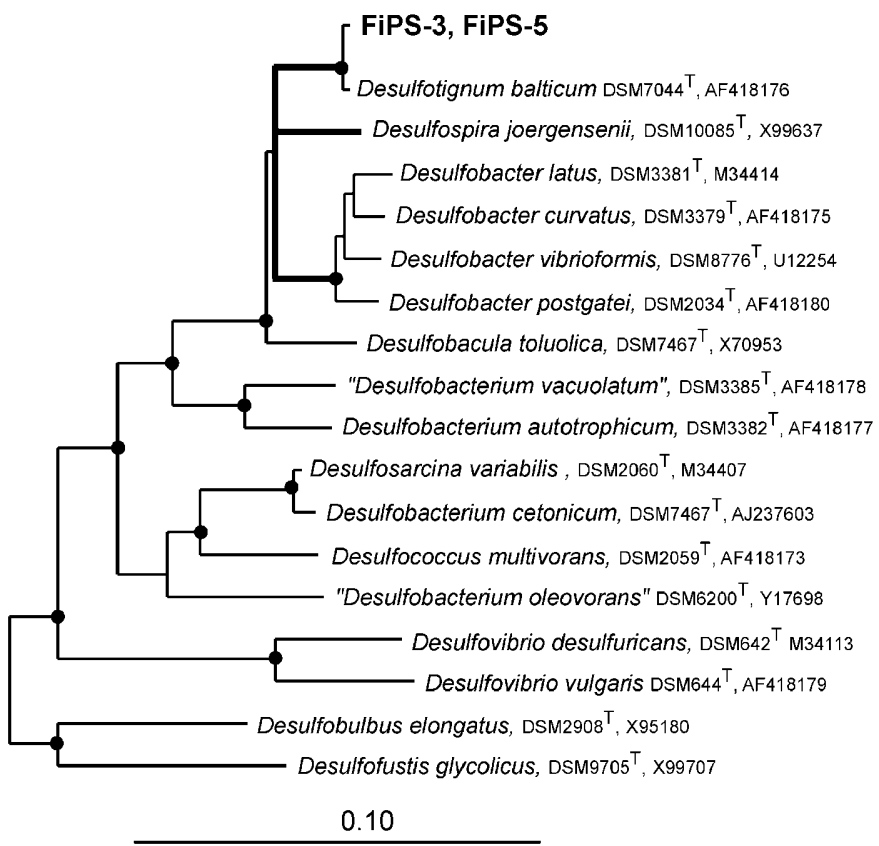

Phylogenetic analysis

Comparative 16S rRNA sequence analysis revealed that strain FiPS-3 showed high sequence similarities with sulfate-reducing Proteobacteria of the $\delta$ subclass. Strain FiPS-3 was identical in 16S rDNA sequence $(1,438 \mathrm{bp}$, positions 30-1450, E. coli numbering) to strain FiPS-5, and both were most closely related to Desulfotignum balticum strain $\operatorname{Sax}^{\mathrm{T}}$ (Kuever et al. 2001) (99.7\% sequence similarity; Fig. 3A) followed by Desulfospira joergensenii (Finster et al. 1997) (94.2\%), and Desulfobacula toluolica (93.4\%) (Rabus et al. 1993). Likewise, the DsrAB amino acid sequence of FiPS-3 as translated from the corresponding gene sequence showed high similarity to the sequences of Desulfotignum balticum dsrAB clones (99.3-99.8\%). The sequences of these clones were not identical to each other as indicated by the presence of unambiguous nucleotide differences, which suggests the presence of multiple $d s r A B$ gene copies in $D$. balticum. Other closely related

Fig. 3 Phylogenetic position of the phosphite-oxidizing, sulfatereducing strains FiPS-3 and FiPS-5 in relation to members of the genus Desulfobacter, as well as Desulfobacula toluolica, Desulfospira joergensenii, and other representatives of major lineages of the $\delta$-Proteobacteria as derived from (A) $16 \mathrm{~S}$ rDNA- and (B) DsrAB-based dendrograms. Phylogenetic trees were constructed using distance-matrix-based neighbor-joining analysis. Desulfobulbus elongatus and Desulfofustis glycolicus were used as the outgroup reference. The "multifurcations" (Ludwig et al. 1998) indicate that a common significant branching order could not be found; "multifurcations" are indicated by thick lines. Bootstrap support values were obtained from neighbor-joining and parsimony analyses (1,000 resamplings each). Filled circles indicate nodes with a bootstrap support of $>80 \%$ for both analyses. Dba, Desulfobacula; Dbb, Desulfobulbus; Dbc, Desulfobacter; Dbm, Desulfobacterium; Dsc, Desulfococcus; Dsf, Desulfofustis; Dss, Desulfosarcina; Dst, Desulfotignum; Dsv, Desulfovibrio. Scale bars 0.1 changes per nucleotide (A) or amino acid positions (B)

\section{B. DsrAB}

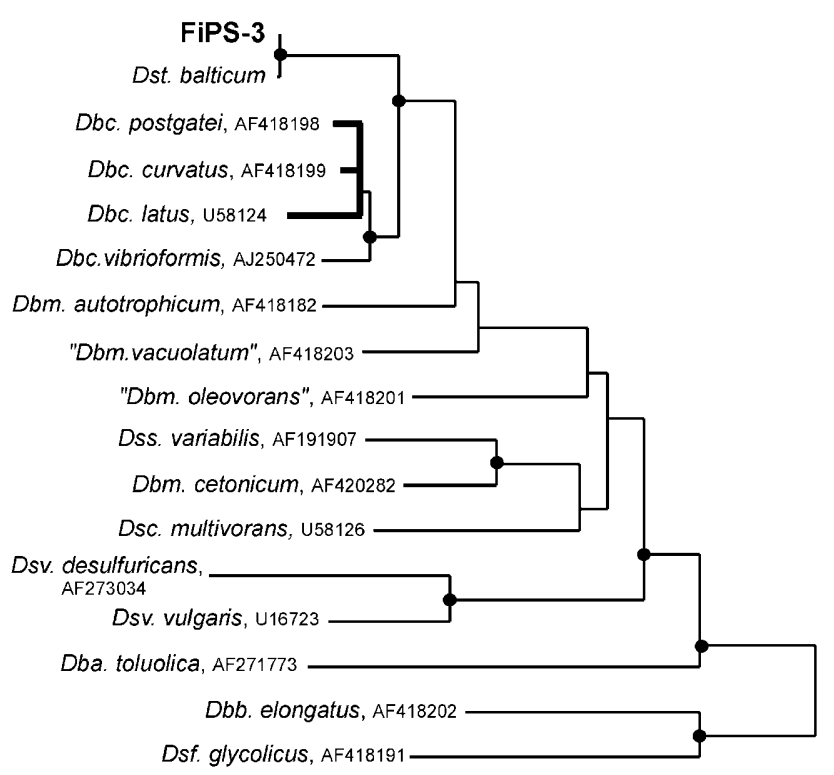


strains were Desulfobacter spp. (Fig. 3B), which was in agreement with the 16S rDNA tree topology.

Supplementary tests with other sulfate reducers

For completion of a comparison of strain FiPS-3 with the strains that appeared to be most closely related to it on the basis of 16SrRNA and $d s r A B$ sequence analyses, further substrate tests were carried out with Desulfotignum balticum and Desulfospira joergensenii, neither of which grew with phosphite. Also, the $\mathrm{G}+\mathrm{C}$ content of the DNA of D. balticum strain Sax was checked again by the DSMZ, Braunschweig, Germany. The results of these tests are documented in Table 2 and are discussed below in the context of the taxonomic affiliation of the new strain.

\section{Discussion}

Strain FiPS-3 was isolated from a marine sediment with phosphite as sole electron source and sulfate as electron acceptor. The strain is of interest for several reasons: (1) it performs a redox reaction with phosphite, (2) it can form acetate by homoacetogenic fermentation in the absence of sulfate, (3) it uses sugars and some amino acids as substrates, combining sulfate reduction with a fermentative metabolism, (4) it obviously conserves metabolic energy in a redox reaction with an electron donor of unusually low redox potential.

\section{Physiology}

Strain FiPS-3 grows lithoautotrophically with phosphite as sole electron donor and sulfate as electron acceptor according to the equation:

$4 \mathrm{HPO}_{3}{ }^{2-}+\mathrm{SO}_{4}{ }^{2-}+\mathrm{H}^{+} \rightarrow 4 \mathrm{HPO}_{4}{ }^{2-}+\mathrm{HS}^{-}$

$\Delta G^{\circ}=-364 \mathrm{~kJ}$ per mol sulfate, or $-91 \mathrm{~kJ}$ per mol phosphite.

In addition, hydrogen or formate was used for autotrophic growth, and the presence of carbon monoxide dehydrogenase and the absence of 2-oxoglutarate dehydrogenase activity both indicate that this bacterium uses the acetyl-CoA pathway ("Wood pathway") for cell carbon assimilation. The same pathway is obviously used for energy metabolism in the absence of sulfate as electron acceptor: Under these conditions, the bacterium reduces $\mathrm{CO}_{2}$ to acetate, according to the equation:

$4 \mathrm{HPO}_{3}{ }^{2-}+2 \mathrm{CO}_{2}+2 \mathrm{H}_{2} \mathrm{O} \rightarrow 4 \mathrm{HPO}_{4}{ }^{2-}+\mathrm{CH}_{3} \mathrm{COO}^{-}+\mathrm{H}^{+}$

$\Delta G^{\circ}=-308 \mathrm{~kJ}$ per mol acetate, or $-77 \mathrm{~kJ}$ per mol phosphite.

Strain FiPS-3 can also grow with some sugars, i. e., glucose, arabinose, and xylose, as substrates, a capacity which is still unusual among sulfate-reducing bacteria. So far, only Desulfotomaculum nigrificans (Klemps et al.
1985) Desulfovibrio fructosovorans (Cord-Ruwisch et al. 1986; Ollivier et al. 1988), Desulfovibrio simplex (Zellner et al. 1989), Desulfovibrio termitidis (Trinkerl et al. 1990) and Desulfovibrio zosterae (Nielsen et al. 1999) have been described to use sugars, and they do so also rather slowly. Slow growth and the comparably low growth yields observed with strain FiPS-3 on sugars indicate that this bacterium is rather inefficient in using these substrates and could hardly compete with this capacity against a fast-growing fermenting bacterium, e.g., in an enrichment culture. Sugars were partly oxidized with concomitant sulfate reduction and partly fermented to a mixture of acetate and propionate. Unusual among sulfate reducers as well is the capacity of strain FiPS-3 to use amino acids as substrates. To date, mainly glycine, alanine, serine and glutamate have been reported to be oxidized by sulfate reducers (Widdel and Hansen 1992). Strain FiPS-3 cannot oxidize alanine, but uses glutamate and glycine. Proline also proved to be an excellent substrate, as is the case for Desulfospira joergensenii (Finster et al. 1997). Unusual among sulfate reducers, on the other hand, is the inability of strain FiPS-3 to grow with ethanol or lactate since these are common substrates for the majority of known sulfate reducers (Widdel and Hansen 1992). Acetate is oxidized only in the presence of hydrogen as a cosubstrate; obviously, the bacteria have difficulties in exploiting the small energy span available in sulfate-dependent acetate oxidation. Lack of oxidation of longer-chain fatty acids may be due to an energetic problem as well. This may also explain why propionate is not oxidized with sulfate even though the bacteria should have all the enzymes required for propionate oxidation, since they can form propionate from sugars.

\section{Energetics and enzymology}

Compared to growth with formate, the cell yield with phosphite was substantially higher, indicating that the bacterium can exploit the energy provided with this redox process, which allows the formation of more than $1 \mathrm{~mol}$ ATP per mol phosphite oxidized. One mol ATP can fuel the formation of $10 \mathrm{~g}$ cell material under good growth conditions (Stouthamer 1979). The observed cell yield of strain FiPS-3 on phosphite is close to this figure, although growth with phosphite is autotrophic and requires the synthesis of all cell constituents from $\mathrm{CO}_{2}$. Typically, autotrophic growth is associated with lower cell yields, i. e., 2-3 g cell matter per mol ATP (Stouthamer 1979), but the very energy-efficient Wood pathway for autotrophic cell matter synthesis allows higher growth yields. Perhaps the unusually high yields we observe are due to the fact that phosphite electrons arise at a very low redox potential (see below). Furthermore, the growth yields of sulfate-independent homoacetogenic phosphite oxidation are in the same range as in the presence of sulfate.

The substantial difference in cell yields after growth with phosphite as compared to growth with formate documents that strain FiPS-3 obviously can exploit the free en- 
ergy change associated with Eqs. 1 and 2 or, more precisely, can make use of the redox potential difference between the phosphate/phosphite $\left(E_{0}{ }^{\prime}=-690 \mathrm{mV}\right)$ and the $\mathrm{CO}_{2}$ /formate couple $\left(E_{0}{ }^{\prime}=-430 \mathrm{mV}\right)$. So far, there is only little information on the phosphite-oxidizing enzyme of this bacterium (see below). Nonetheless, no redox carriers in this very low potential range are yet known, and it appears plausible to argue, therefore, that the energy of phosphite oxidation is likely to be conserved mainly through substrate level phosphorylation, in addition to electron transport phosphorylation in sulfate reduction.

Unfortunately, we could not detect a phosphite-oxidizing enzyme activity in cell-free extracts. Such an enzyme should be easily detectable with viologens or acceptors of higher redox potential because the redox potential of phosphite oxidation is very low $\left(E_{0}{ }^{\prime}=-690 \mathrm{mV}\right)$. If one would couple phosphite oxidation with phosphorylation of AMP or ADP, analogous to APS reductase,

$$
\begin{aligned}
\mathrm{HPO}_{3}{ }^{2-} & +\mathrm{ADP}(\mathrm{AMP})+\mathrm{H}_{2} \mathrm{O} \rightarrow \mathrm{ATP}(\mathrm{ADP}) \\
& +2 \mathrm{H}^{+}+2 \mathrm{e}^{-} \mathrm{E}^{\prime}{ }_{(\text {physiol })}
\end{aligned}
$$

the redox potential would be shifted to $-432 \mathrm{mV}$ if about $50 \mathrm{~kJ}$ would be spent in the formation of an energy-rich phosphoric acid anhydride linkage, taking the concentrations of ATP and ADP in the growing cell into account (Thauer et al. 1977). One could as well assume that any kind of acid, either a low-molecular-mass acid or a carboxylic group of the oxidizing protein, could act as primary phosphite acceptor, and could this way help to conserve the free energy of this oxidation, as was suggested recently by Buckel (2001). So far, we have not succeeded in demonstrating any phosphite-oxidizing enzyme activity in cell-free extracts, perhaps because the right co-substrate(s) was not employed. Alternative candidates could be other nucleotide phosphates, acids, thiols, etc. This will be subject to further studies in our laboratory.

Analysis of the protein pattern by SDS-PAGE clearly showed a protein band that was specifically induced after growth with phosphite. This protein had a molecular mass of about $42 \mathrm{kDa}$, which differs from that of the recently described NAD-reducing assimilatory phosphite dehydrogenase of Pseudomonas stutzeri (36.2 kDa; Garcia Costas et al. 2001). Although this enzyme probably performs a new and interesting type of NAD reduction (Vrtis et al. 2001), there is no indication of the involvement of substrate-level phosphorylation in this oxidation, and we therefore do not expect a high degree of resemblance between the two enzymes. A further hypophosphite- and phosphite-oxidizing enzyme activity was reported earlier for Bacillus caldolyticus (Heinen and Lauwers 1974), but this old report does not provide detailed information on the biochemistry of these activities.

Some further observations may be important in the context of the phosphite-oxidizing enzyme system of strain FiPS-3. We did not succeed in detecting phosphotransacetylase and acetate kinase activity in our strain, two key enzymes in energy metabolism of sulfate reducers that are usually easy to detect. Either these enzymes simply do not exist in this bacterium (which would explain why it has difficulties growing with acetate and higher fatty acids) or these enzymes exist in modified forms that are not so easily assessed by the conventional enzyme tests. The puzzling observation that sulfite inhibited phosphite oxidation more strongly than, e.g., fumarate oxidation may be another hint that both anions interfere in the cell with the same enzyme system.

If phosphite oxidation is associated with substratelevel phosphorylation analogous to Eq. 3, the electrons are released at a rather low potential that could still allow reduction of, e.g., $\mathrm{NAD}^{+}$. Thus, a strict separation between electrons used either for energy metabolism or for assimilatory metabolism does not make sense in this type of metabolism: electrons can do "work" in ATP synthesis, and still be valuable for cell carbon assimilation. This potential double function of electrons may help to explain the comparably high growth yields discussed above.

\section{Ecology}

The ecological role of dissimilatory phosphite oxidation in nature is still unclear. On today's oxygen-exposed Earth, phosphite and other reduced inorganic phosphorus compounds are not stable as minerals. Phosphite might play a role as an intermediate in microbial degradation of organophosphonates in strictly anoxic habitats, but there is no experimental evidence of such a reaction sequence so far; aerobic bacteria release the phosphorus residue of organophosphonates as phosphate, probably via a radical cleavage reaction (Wackett et al. 1987; Vandepitte and Verstraete 1995; McGrath et al. 1998). In prebiotic and archaean times, reduced phosphorus compounds may have been more important. Phosphonic acids have been suggested as evolutionary precursors of biological phosphate compounds (Schwartz 1997a, b). An involvement of phosphite radicals in the synthesis of phosphonoacetaldehyde, an analogue of glycolaldehyde phosphate, has been reported (DeGraaf et al. 1995). Reduced phosphorus compounds might have been introduced by meteorites (Cooper et al. 1992) or produced during core formation of the early Earth (Schwartz 1997a). Recently, electrical discharges associated with volcanic eruptions were proposed as possible sources of phosphite formation (Glindemann et al. 1999). Thus, it appears plausible to speculate that the (oxygen-free) early Earth might have contained reduced phosphorus compounds. Anaerobically respiring microorganisms such as the sulfate reducers described here may have thrived on a litho(auto)trophic metabolism oxidizing reduced phosphorus compounds; therefore, dissimilatory phosphite oxidation by sulfate-reducing bacteria may be regarded as an ancient evolutionary trait.

\section{Taxonomy}

The closest relative of strain FiPS-3 is Desulfotignum balticum (Kuever et al. 2001) based on both 16S rDNA 
and $\operatorname{dsr} A B$ sequence analysis $(99.7 \%$ and $99.6-99.7 \%$ similarity, respectively). The sequence differences were only small (Fig. 3A, B), and thus both strains could be attributed to the same species according to the widely used, pragmatic 16S rDNA-based species concept that requires at least $97 \%$ sequence similarity within one species (Stackebrandt and Goebel 1994). However, since the 16S rRNA is a very conserved molecular marker it may not resolve phenotypically different species (Rossello-Mora and Amann 2001). In fact, on the basis of physiological properties, it is obvious that strain FiPS-3 differs substantially form both $D$. balticum and $D$. joergensenii. As shown in Table 2, neither D. balticum nor $D$. joergensenii is able to grow with phosphite, the key capacity of strain FiPS-3. There are also substantial differences with respect to the utilization of fatty acids or sugars as substrates. We therefore suggest to establish a new species within the genus Desulfotignum, Desulfotignum phosphitoxidans, with strain FiPS-3 as type strain. A formal description of the new species follows.

Description of Desulfotignum phosphitoxidans sp. nov.

Desulfotignum phosphitoxidans sp. nov. phos.phit.o'xi.dans. M.L. adj. phosphitoxidans oxidizing phosphite, referring to its utilization of this unusual electron source.

Rod-shaped cells, $0.6-0.8 \mu \mathrm{m}$ wide and $2-4 \mu \mathrm{m}$ long, with pointed ends, gram-negative, non-sporing, non-motile. Strictly anaerobic chemotroph, reducing sulfate, thiosulfate or sulfite, and oxidizing a broad variety of substrates, including phosphite, hydrogen, formate, fumarate, malate, pyruvate, glucose, arabinose, xylose, glycine, betaine, proline, glutamate, yeast extract.

Lithoautotrophic growth with phosphite, hydrogen, or formate; acetate not required for growth. Acetate is co-oxidized in the presence of hydrogen, but does not support growth on its own. In the absence of sulfate, phosphite is fermented to phosphate with acetate as reduced product. Carbon monoxide dehydrogenase present.

Thiophosphate, ethanol, propanol, lactate, propionate, butyrate, crotonate, malonate, succinate, glutarate, 2-oxoglutarate, 3-oxoglutarate, choline, alanine, fructose, and ribose not used. Thiosulfate not dismutated. Growth requires mineral media with sulfide as reductant. Growth is optimal in brackish water or saltwater medium, with at least $10 \mathrm{~g} \mathrm{NaCl}$ and $1.5 \mathrm{~g} \mathrm{MgCl}_{2}$ per 1 .

$\mathrm{pH}$ range 5.0-8.0, optimum at $\mathrm{pH}$ 6.9-7.2. Temperature range $15-30^{\circ} \mathrm{C}$, optimum at $30^{\circ} \mathrm{C}$.

Cells contain cytochromes $b$ and $c$ and desulforubidin.

DNA base ratio: $53.9 \mathrm{~mol} \% \mathrm{G}+\mathrm{C}$.

Habitat: anoxic marine and brackish sediments.

Type strain: FiPS-3, deposited as DSM 13687 with the Deutsche Sammlung von Mikroorganismen und Zellkulturen, Braunschweig, Germany, and as OCM 818 with the Oregon Collection of Methanogens, Portland, OR, USA.
Acknowledgements The authors are grateful to Dr. Peter Schumann, DSMZ Braunschweig, for determining the $\mathrm{G}+\mathrm{C}$ content of strain FiPS-3 and strain SAX, to Jürgen Felsche and Gerhard Wildermuth for X-ray analysis of phosphate crystals, to Elisabeth Kayser for performing substrate utilization tests, and to Bianca Wagner for sequencing. Thomas Büchert, Konstanz, supplied a sample of purified APS reductase of Desulfovibrio desulfuricans. This study was supported by grants of the Universität Konstanz, the Fonds der Chemischen Industrie, Frankfurt/Main, and the Max-Planck-Gesellschaft, Munich, Germany.

\section{References}

Barrenscheen HK, Beckh-Widmanstetter HA (1923) Über bakterielle Reduktion organisch gebundener Phosphorsäure. Biochem Z 140:279-283

Bergmeyer HU, Gawehn K, Grassl M (1974a) Acetat-Kinase. In: Bergmeyer HU (ed) Methoden der enzymatischen Analyse. Verlag Chemie, Weinheim, pp 454-455

Bergmeyer HU, Gawehn K, Grassl M (1974b) Phosphotransacetylase. In: Bergmeyer HU (ed) Methoden der enzymatischen Analyse. Verlag Chemie, Weinheim, pp 541-542

Brune A, Schink B (1990) Pyrogallol-to-phloroglucinol conversion and other hydroxyl-transfer reactions catalyzed by cell extracts of Pelobacter acidigallici. J Bacteriol 172:1070-1076

Buckel W (2001) Anorganische Chemie in Meeressedimenten. Angew Chem 113:1463-1464

Cashion P, Holder-Franklin MA, McCully J, Franklin M (1977) A rapid method for the base ratio determination of bacterial DNA. Anal Biochem 81:461-466

Casida LE Jr (1960) Microbial oxidation and utilization of orthophosphite during growth. J Bacteriol 80:237-241

Cline JD (1969) Spectrophotometric determination of hydrogen sulfide in natural waters. Limnol Oceanogr 14:454-458

Cooper GW, Onwo WM, Cronin JR (1992) Alkyl phosphonicacids and sulfonic-acids in the Murchison meteorite. Geochim Cosmochim Acta 56:4109-4115

Cord-Ruwisch R, Ollivier B, Garcia JL (1986) Fructose degradation by Desulfovibrio sp. in pure culture and in coculture with Methanospirillum hungatei. Curr Microbiol 12:285-289

Dahl C, Trüper HG (1994) Enzymes of dissimilatory sulfide oxidation in phototrophic bacteria. Methods Enzymol 243:400421

De Graaf, Visscher J, Schwartz AW (1995) A plausibly prebiotic synthesis of phosphonic acids. Nature 378:474-477

Devai I, DeLaune RD (1995) Evidence for phosphine production and emission from Louisiana and Florida marsh soils. Org Geochem 23:277-279

Devai I, Felföldy L, Wittner I, Plosz S (1988) Detection of phosphine: new aspects of the phosphorous cycle in the hydrosphere. Nature 333:343-345

Devai I, DeLaune RD, Devai G, Patrick WH, Czegeny I (1999) Phosphine production potential of various wastewater and sewage sludge sources. Anal Lett 32:1447-1457

Diekert G, Thauer RK (1978) Carbon monoxide oxidation by Clostridium thermoaceticum and Clostridium formicoaceticum. J Bacteriol 136:597-606

Ferris MJ, Ward DM (1997) Seasonal distributions of dominant 16S rRNA-defined populations in a hot spring microbial mat examined by denaturing gradient gel electrophoresis. Appl Environ Microbiol 63:1375-1381

Finster K, Liesack W, Tindall BJ (1997) Desulfospira joergensenii, gen. nov., sp. nov., a new sulfate-reducing bacterium isolated from marine surface sediment. Syst App Microbiol. 20: 201-208

Foster TL, Winans L, Elms SJS (1978) Anaerobic utilization of phosphite and hypophosphite by Bacillus sp. Appl Environ Microbiol 35:937-944 
Friedrich MW (2002) Phylogenetic analysis reveals multiple lateral transfers of adenosine-5'-phosphosulfate reductase genes (apsA) among sulfate-reducing microorganisms. J Bacteriol 184:278-289

Friedrich M, Schink B (1995) Isolation and characterization of a desulforubidin-containing sulfate-reducing bacterium growing with glycolate. Arch Microbiol 164:271-279

Garcia Costas AM, White AK, Metcalf WW (2001) Purification and characterization of a novel phosphorus-oxidizing enzyme from Pseudomonas stutzeri WM88. J Biol Chem 20:1742917436

Gassmann G, Glindemann D (1993) Phosphane $\left(\mathrm{PH}_{3}\right)$ in the biosphere. Ang Chem. 32:761-763

Gassmann G, Schorn F (1993) Phosphine from harbor surface sediments. Naturwissenschaften 80:78-80

Glindemann D, Eismann F, Bergmann A, Kuschk P, Stottmeister U (1998) Phosphine by bio-corrosion of phosphide-rich iron. Environ Sci Pollut Res 5:71-74

Glindemann D, De Graaf RM, Schwartz AW (1999) Chemical reduction of phosphate on the primitive Earth. Orig Life Evol Biosph 29:555-561

Han S-H, Zhuang Y-H, Liu J-A, Glindemann D (2000) Phosphorus cycling through phosphine in paddy fields. Sci Total Environ 258:195-203

Heinen W, Lauwers AM (1974) Hypophosphite oxidase from Bacillus caldolyticus. Arch Mikrobiol 95:267-274

Horiguchi M (1984) Biochemistry of natural C-P compounds. In: Hori T, Horiguchi M, Hayashi A (eds) Japanese Association for Research on the Biochemistry of C-P compounds. Shiga, Japan, pp 24-52

Jenkins RO, Morris T-A, Craig PJ, Ritchie AW, Ostah N (2000) Phosphine generation by mixed- and monoseptic-cultures of anaerobic bacteria. Sci Total Environ 250:73-81

Kim A, Kim J, Martin BM, Dunaway-Mariano D (1998) Isolation and characterization of the carbon-phosphorus bond-forming enzyme phosphoenolpyruvate mutase from the mollusk Mytilus edulis. J Biol Chem 273:4443-4448

Klemps R, Cypionka H, Widdel F, Pfennig N (1985) Growth with hydrogen, and further physiological characteristics of Desulfotomaculum species. Arch Microbiol 143:203-208

Kuever J, Könneke M, Galushko A, Drzyzga O (2001) Reclassification of Desulfobacterium phenolicum as Desulfobacula phenolica comb. nov. and description of strain $\operatorname{Sax}^{\mathrm{T}}$ as Desulfotignum balticum gen. nov., sp. nov. Int J Syst Evol Microbiol 51:171-177

Laemmli UK (1970) Cleavage of structural proteins during the assembly of the head of bacteriophage T4. Nature 227:680-685

Lampreia J, Pereira AS, Moura JJG (1994) Adenylsulfate reductases from sulfate-reducing bacteria. Meth Enzymol 243:241260

Lane DJ (1991) 16S/23S rRNA sequencing. In: Stackebrandt E, Goodfellow M (eds) Nucleic acids techniques in bacterial systematics. Wiley, Chichester, pp 115-147

Ludwig W, Strunk O, Klugbauer S, Klugbauer N, Weizenegger M, Neumaier J, Bachleitner M, Schleifer KH (1998) Bacterial phylogeny based on comparative sequence analysis. Electrophoresis 19:554-568

Malacinski G, Konetzka WA (1966) Bacterial oxidation of orthophosphite. J Bacteriol 91:578-582

McGrath JW, Hammerschmidt F, Quinn JP (1998) Biodegradation of phosphonomycin by Rhizobium huakuii PMY1. Appl Environ Microbiol 64:356-358

Mesbah M, Premachandran U, Whitman WB (1989) Precise measurement of the $\mathrm{G}+\mathrm{C}$ content of deoxyribonucleic acid by highperformance liquid chromatography. Int J Syst Bacteriol 39: 159-167

Metcalf WW, Wolfe RS (1998) Molecular genetic analysis of phosphite and hypophosphite oxidation by Pseudomonas stutzeri WM88. J Bacteriol 180:5547-5558
Nielsen JT, Liesack W, Finster K (1999) Desulfovibrio zosterae sp. nov., a new sulfate reducer isolated from surface-sterilized roots of the seagrass Zostera marina. Int J Syst Bacteriol 49: 859-65

Ollivier B, Cord-Ruwisch R, Hatchikian EC, Garcia JL (1988) Characterization of Desulfovibrio fructosovorans sp. nov. Arch Microbiol 149:447-450

Phelps CD, Kerkhof LJ, Young LY (1998) Molecular characterization of a sulfate-reducing consortium which mineralizes benzene. FEMS Microbiol Ecol 27:269-279

Platen H, Schink B (1987) Methanogenic degradation of acetone by an enrichment culture. Arch Microbiol 149:136-141

Postgate JR (1959) A diagnostic reaction of Desulphovibrio desulphuricans. Nature 183:481-482

Rabus R, Nordhaus R, Ludwig W, Widdel F (1993) Complete oxidation of toluene under strictly anoxic conditions by a new sulfate-reducing bacterium. Appl Environ Microbiol 59:14441451

Rossello-Mora R, Amann R (2001) The species concept for prokaryotes. FEMS Microbiol Rev 25:39-67

Rotthauwe JH, Witzel KP, Liesack W (1997) The ammonia monooxygenase structural gene amoA as a functional marker: molecular fine-scale analysis of natural ammonia-oxidizing populations. Appl Environ Microbiol 63:4704-4712

Rudakow KJ (1929) Die Reduktion der mineralischen Phosphate auf biologischem Wege. Centralbl Bakteriol Infektionskr 29: 229-245

Rutishauser BV, Bachofen R (1999) Phosphine formation from sewage sludge cultures. Anaerobe 5:525-531

Schink B, Friedrich M (2000) Phosphite oxidation by sulphate reduction. Nature 406:37

Schwartz AW (1997a) Prebiotic phosphorus chemistry reconsidered. Orig Life Evol Biosphere 27:505-512

Schwartz AW (1997b) Speculation on the RNA precursor problem. J Theoret Biol 187:523-527

Stackebrandt E, Goebel BM (1994) Taxonomic note: A place for DNA-DNA reassociation and 16S rRNA sequence analysis in the present species definition in bacteriology. Int J Syst Bacteriol 44:846-849

Stouthamer AH (1979) The search for correlation between theoretical and experimental growth yields. Int Rev Biochem Microb Biochem 21:1-47

Tamaoka J, Komagata K (1984) Determination of DNA base composition by reversed-phase high-performance liquid chromatography. FEMS Microbiol Lett 25:125-128

Ternan NG, Mc Grath JW, Mc Mullan G, Quinn JP (1998) Organophosphonates: occurrence, synthesis and biodegradation by microorganisms. World Microbiol Biotechnol 14:635-647

Thauer RK, Jungermann K, Decker K (1977) Energy conservation of chemotrophic anaerobic bacteria. Bacteriol Rev 41:100-180

Trinkerl M, Breunig A, Schauder R, König H (1990) Desulfovibrio termitidis $\mathrm{sp}$. nov., a carbohydrate-degrading sulfate-reducing bacterium from the hindgut of a termite. Syst Appl Microbiol $13: 372-377$

Tsubota G (1959) Phosphate reduction in the paddy field I. Soil Plant Food 5:10-15

Vandepitte V, Verstraete W (1995) Homolytic carbon to phosphorus bond scission of some phosphonates catalyzed by bacterial carbon-phosphorus lyase. Biodegradation 6:157-165

Vrtis JM, White AK, Metcalf WW, van Der Donk WA (2001) Phosphite dehydrogenase: an unusual phosphoryl transfer reaction. J Am Chem Soc 123:2672-2673

Wackett LP, Shames SL, Venditti CP, Walsh CT (1987) Bacterial carbon-phosphorus lyase - products, rates, and regulation of phosphonic and phosphinic acid metabolism. J Bacteriol 169: 710-717

Wagner M, Roger AJ, Flax JL, Brusseau GA, Stahl DA (1998) Phylogeny of dissimilatory sulfite reductases supports an early origin of sulfate respiration. J Bacteriol 180:2975-2982

Weast RC, Astle MJ, Beyer WH (eds)(1988) CRC handbook of chemistry and physics. CRC Press, Boca Raton, Florida 
Weisburg WG, Barns SM, Pelletier SA, Lane DJ (1991) 16S ribosomal DNA amplification for phylogenetic study. J Bacteriol 173:697-703

Weston JA, Knowles CJ (1973) A soluble CO-binding $c$-type cytochrome from the marine bacterium Beneckea natriegens. Biochim Biophys Acta 305:11-18

Widdel F, Pfennig N (1981) Studies on dissimilatory sulfate-reducing bacteria that decompose fatty acids. I. Isolation of a new sulfate-reducer enriched with acetate from saline environments - description of Desulfobacter postgatei gen. nov. sp. nov. Arch Microbiol 129:395-400
Widdel F, Bak F (1992) Gram-negative mesophilic sulfate-reducing bacteria. In: Balows A, Trüper HG, Dworkin M, Harder W, Schleifer KH (eds) The prokaryotes. Springer, Berlin Heidelberg New York, pp 3352-3378

Widdel F, Hansen TA (1992) The dissimilatory sulfate- and sulfurreducing bacteria. In: Balows A, Trüber HG, Dworkin $\mathrm{M}$, Harder W, Schleifer KH (ed) The prokaryotes, 2nd edn. Springer, Berlin Heidelberg New York, pp 583-624

Zellner G, Messner P, Kneifel H, Winter J (1989) Desulfovibrio simplex spec. nov., a new sulfate-reducing bacterium from a sour whey digester. Arch Microbiol 152:329-334 